This is an Accepted Manuscript of an article published by Taylor \& Francis in Economic Systems Research on 2018, available online: http://www.tandfonline.com/10.1080/09535314.2017.1357536.

\title{
The opportunity costs of commuting: the value of a commuting satellite account framework with an example from Lisbon Metropolitan Area*
}

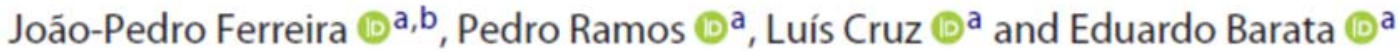 \\ ${ }^{a}$ CeBER and Faculty of Economics, University of Coimbra, Coimbra, Portugal; ${ }^{b}$ Research Unit on Governance, \\ Competitiveness and Public Policies (GOVCOPP), Aveiro, Portugal
}

\begin{abstract}
Commuting affects regional and urban economies. It shapes urban areas, defines their relationships with neighboring regions, intensifies economic flows and exacerbates energy consumption and greenhouse gas emissions. This paper sets out a proposal for an innovative commuting satellite account (CSA), integrated in a multiregional input-output model. This framework combines commuting activities with regional distribution of income, distinct household consumption structures, real estate renting activities and the energy consumption and environmental flows incorporated in the different industries. To assess the opportunity costs of commuting, the CSA framework is applied to the Lisbon Metropolitan Area. The socioeconomic-environmental impacts of a scenario in which commuters become non-commuters by moving their residence to the municipality in which they work are estimated. The analysis indicates that: commuting, in general, induces significant economic and environmental opportunity costs. Finally, the adoption of policy-oriented recommendations contributing to limit sprawling in metropolitan regions is discussed.
\end{abstract}

\section{ARTICLE HISTORY}

Recelved 29 February 2016 In final form 17 July 2017

\section{KEYWORDS}

Commuting; environmental impacts; metropolitan areas; multi-regional input-output analysis; satellite accounts 


\section{Introduction}

Commuting plays a central role in regional and urban economies by shaping the social, economic and environmental dimensions of metropolitan regions. However, commuting impacts have often been either ignored or typically seen as the "market working just fine" (Ewing, 1997). Commuting is fundamental to provide a vital input (workforce) for production activities and is simultaneously a mandatory routine for working households to secure their income. Indeed, it is indisputable that the growth of commuting makes a critical contribution to stretching the boundaries of urban areas and exacerbates energy consumption and greenhouse gas emissions. Cities concentrate most economic activities worldwide and the $21^{\text {st }}$ century metropolitan regions pose new geographical challenges that further extend and intensify economic and demographic interdependence (Fujita et al., 1999). In short, commuting demands the application of more holistic approaches.

This work aims to appraise the opportunity costs of commuting by assessing its multidimensional impacts, while accurately characterizing the economic and geographic context where this phenomenon takes place. First we discuss the grounds and relevance of considering a 'commuting satellite account' (CSA), where statistical data from different sources are consistently combined with a multi-regional input-output (MRIO) framework. An MRIO framework is used to model the linkages between industries and households located in different regions, i.e., the potential of these approaches goes far beyond the single region model effects as they allow a more detailed allocation of the impacts associated with regional structural specificities and the identification of the regional spillover effects (Miller and Blair, 2009). This is particularly important for neighboring regions with intensive trade flows and interregional income distribution. So, the proposed CSA attaches commuting to the traditional MRIO framework, and then this modeling approach is tested on a real world case study: the Lisbon Metropolitan Area (LMA), the most densely populated urban region in Portugal. The proposed CSA framework is expected to be a major contribution to a thorough understanding of the complex phenomenon of commuting. In this vein, it should provide results that allow a more adequate set of policies contributing to achieve the broader aims of economic growth, well-being and a more sustainable urban environment.

\section{A commuting satellite account}

In this section we present an extension to the traditional interactions and flows represented in typical MRIO frameworks to better specify the critical elements of commuting that largely influence the relationships between economic agents within a metropolitan area. The following dimensions, all 
incorporated together, are the core of the proposed CSA and are developed in the subsections that follow.

(1) Commuting takes place in (and is influenced by) a specific geographic and economic context. Subsection 2.1 discusses the structure of our CSA, embedded in an MRIO model.

(2) Household commuters' expenditure in a specific region depend on the income generated by industries located in other regions. Subsection 2.2 explores the incorporation of regional income distribution.

(3) Different commuting patterns imply distinct household consumption structures (Ferreira et al., 2014). Subsection 2.3 specifies how this transformation is incorporated.

(4) Travel-to-work journeys link the workplace and the place of residence, and therefore commuting influences rent prices of both housing and business premises (Malpezzi, 1996). Subsection 2.4 considers these relationships.

(5) Commuting is a major cause of energy consumption and $\mathrm{CO}_{2}$ emissions. Subsection 2.5 explains the process of simultaneously integrating the CSA components and an environmental extension within the MRIO framework.

The above dimensions are widely acknowledged in the literature, but, to the best of our knowledge, regional and urban economic studies still lack a modeling framework capable of incorporating all of them within the economic context of a specific region.

\subsection{The CSA structure}

Satellite accounts are flexible forms of taking the full set of rules and conventions of the System of National Accounts (SNA) to provide a framework that enables attention to be focused on a certain field or aspect of economic and social life in the context of national accounts. This research focuses on commuting. The use of satellite accounts is addressed by the two main national accounts handbooks, the System of National Accounts 2008 - SNA 2008 (UN, 2009: Chapter 29) and the European System of National and Regional Accounts - ESA 2010 (Eurostat, 2013: Chapter 22). Like other satellite accounts, each focusing on a particular aspect of interest (e.g., tourism, health or education), the proposed CSA meets the requirement of full consistency with the central framework of the SNA. ${ }^{1}$

\footnotetext{
${ }^{1}$ The CSA has thus strong similarities with other long established satellite accounts. For example, in the tourism satellite account (TSA), the tourism activity "comprises the activities of persons travelling to and staying in places outside their usual environment for less than a year and for a main purpose other than to be employed by a resident entity in the place visited" (Eurostat, 2013). The commuting activity, however, comprises the activities of persons travelling to and staying in places outside their residential location but (routinely and) for a short period of time.
} 
This CSA modeling framework is based on the MULTI2C - multi-sectoral multi-regional Coimbra model developed by researchers from the University of Coimbra, Portugal, which allows the adoption of different geographical configurations and empirical applications. The MULTI2C framework also includes extensions to the regional consumption of primary energy products (in physical terms) and corresponding pollutant emissions (Ramos et al., 2015). Table 1 presents the structure of the proposed CSA, including a brief description of the variables considered and their dimension. To simplify, we consider two regions, A and B, even though our real-world application comprises three regions.

Table 1. The structure of the commuting satellite account

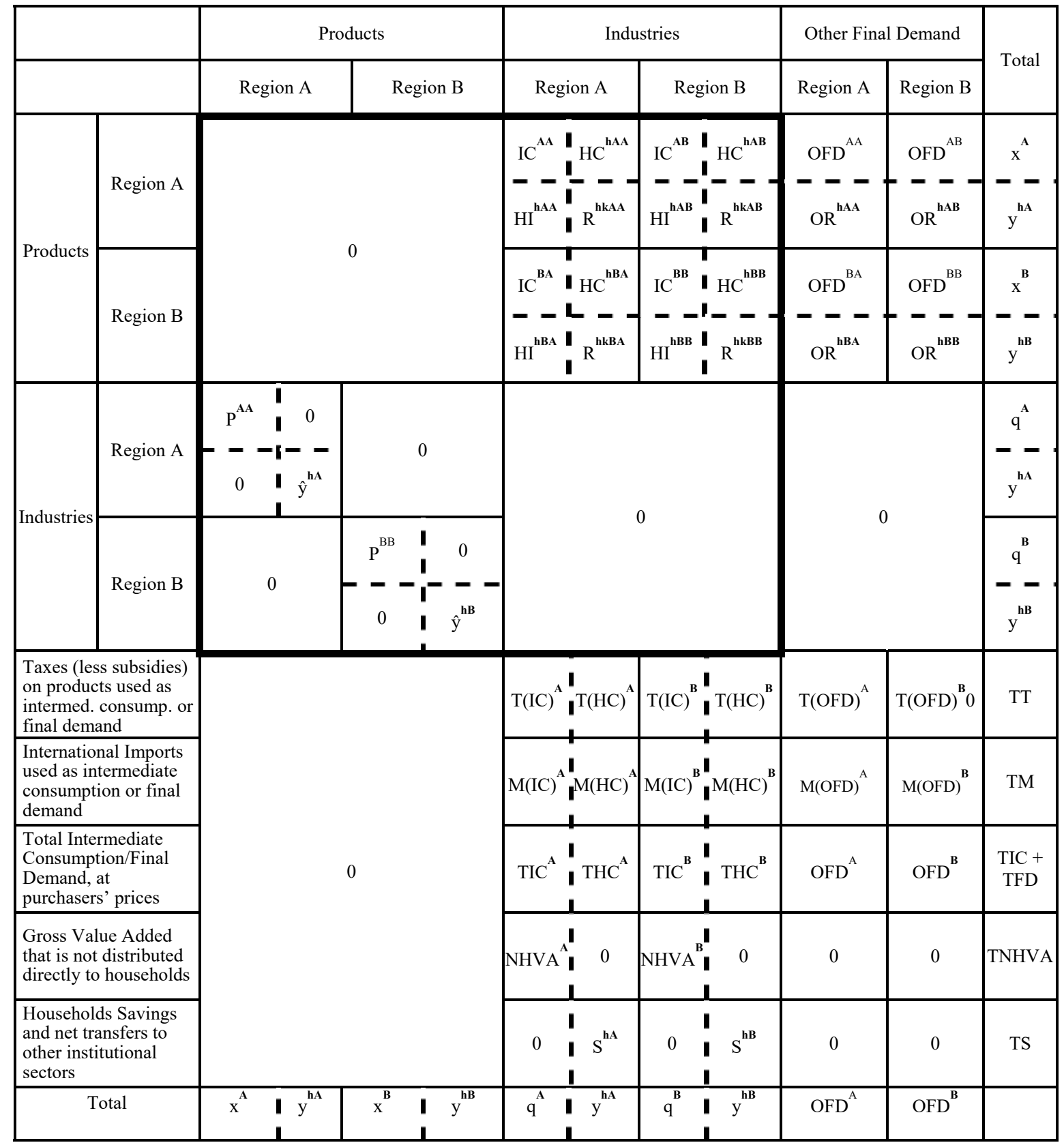




\begin{tabular}{|c|c|c|}
\hline Variable & Description & $\begin{array}{l}\text { Matrices } \\
\text { Dimension* }\end{array}$ \\
\hline$I^{i j}$ & $\begin{array}{l}i=A, B ; j=A, B-\text { Intermediate consumption of region } i \text { products, used } \\
\text { by industries located in region } j \text {. }\end{array}$ & Px I \\
\hline $\mathrm{HC}^{\text {hij }}$ & $\begin{array}{l}i=A, B ; j=A, B-\text { Final consumption of region } i \text { products by type } h \\
\text { households, living in region } j .\end{array}$ & $\mathrm{P} \times \mathrm{H}$ \\
\hline $\mathrm{R}^{\mathrm{hkij}}$ & $\begin{array}{l}i=A, B ; j=A, B-\text { Housing rents paid by type } k \text { households living in } \\
\text { region } j, \text { to households type } h \text { living in region } i \text {. }\end{array}$ & $\mathrm{H} \times \mathrm{H}$ \\
\hline $\mathrm{OFD}^{\mathrm{ij}}$ & $\begin{array}{l}i=A, B ; j=A, B \text { - Other final demand for region } i \text { products, used in } \\
\text { region } j .\end{array}$ & $\mathrm{P} \times 1$ \\
\hline $\mathrm{OR}^{\text {hij }}$ & $\begin{array}{l}i=A, B ; j=A, B-\text { Housing rents paid by the exogenous group of } \\
\text { households in region } j, \text { to households type } h \text { living in region } i \text {. }\end{array}$ & $\mathrm{H} \times 1$ \\
\hline $\mathrm{HI}^{\mathrm{hij}}$ & $\begin{array}{l}i=A, B ; j=A, B-\text { Income received by type } h \text { households living in } \\
\text { region } i \text { (compensation of employees, mixed income and business rents) } \\
\text { paid by industries located in region } j .\end{array}$ & $\mathrm{H} \times \mathrm{I}$ \\
\hline $\mathrm{y}^{\text {hi }}$ & $\begin{array}{l}i=A, B-\text { Total income received by type } h \text { households living in region } i \\
\text { (compensation of employees, mixed income and real estate rents). }\end{array}$ & $\mathrm{Hx} 1$ or $1 \times \mathrm{H}$ \\
\hline$\hat{\mathrm{y}}^{\mathrm{hi}}$ & The same as $y$ hi but in the form of a diagonal matrix. & $\mathrm{H} \times \mathrm{H}$ \\
\hline $\mathrm{x}^{\mathrm{i}}$ & $i=A, B$ - Total products output produced in region $i$, at basic prices. & $\mathrm{P} \times 1$ \\
\hline $\mathrm{P}^{\mathrm{ii}}$ & $i=A, B-$ region $i$ products, according to the producing industry & $\mathrm{IxP}$ \\
\hline$q^{i}$ & $i=A, B-$ region $i$ total industries output, at basic prices & I $x 1$ or $1 \times \mathrm{I}$ \\
\hline $\mathrm{T}(\mathrm{g})^{\mathrm{i}}$ & $\begin{array}{l}g=I C, H C, O F D ; \\
i=A, B ;- \text { Taxes (less subsidies) on products levied in } g, \text { in region } i .\end{array}$ & $\begin{array}{ll}\mathrm{g}=\mathrm{IC} & 1 \times \mathrm{I} \\
\mathrm{g}=\mathrm{HC} & 1 \times \mathrm{H} \\
\mathrm{g}=\mathrm{OFD} & \text { scalar }\end{array}$ \\
\hline TT & Total taxes less subsidies on products & Scalar \\
\hline$M(g)^{i}$ & $\begin{array}{l}g=I C, H C, O F D \\
i=A, B ;- \text { International Imports destined for use in } g, \text { in region } i\end{array}$ & $\begin{array}{ll}\mathrm{g}=\mathrm{IC} & 1 \times \mathrm{I} \\
\mathrm{g}=\mathrm{HC} & 1 \times \mathrm{H} \\
\mathrm{g}=\mathrm{OFD} & \text { scalar }\end{array}$ \\
\hline TM & Total international imports & Scalar \\
\hline $\mathrm{TIC}^{\mathrm{i}}$ & $\begin{array}{l}i=A, B \text { - Total intermediate consumption by industries, in region } i \text {, at } \\
\text { purchasers' prices }\end{array}$ & $1 \times \mathrm{I}$ \\
\hline $\mathrm{THC}^{\mathrm{hi}}$ & $\begin{array}{l}i=A, B \text { - Total region } i \text { consumption by type } h \text { households, at } \\
\text { purchasers' prices (only 'endogenous' household types). }\end{array}$ & $1 \times \mathrm{H}$ \\
\hline $\mathrm{OFD}^{\mathrm{i}}$ & $i=A, B$ - Other final demand in region $i$, at purchasers' prices & Scalar \\
\hline $\mathrm{TIC}+\mathrm{TFD}$ & Total intermediate plus final demand, at purchasers' prices & Scalar \\
\hline NHVA $^{\mathrm{i}}$ & $\begin{array}{l}i=A, B-\text { Gross value added which is not directly distributed to } \\
\text { households, in region } i\end{array}$ & $1 \times \mathrm{I}$ \\
\hline TNHVA & Total Gross value added which is not directly distributed to households & Scalar \\
\hline $\mathrm{S}^{\text {hi }}$ & $\begin{array}{l}i=A, B \text { - Households' savings and net transfers to other institutional } \\
\text { sectors, by type } h \text { household, in region } i\end{array}$ & $1 \times \mathrm{H}$ \\
\hline TS & Total savings and net transfers to other institutional sectors & Scalar \\
\hline
\end{tabular}

* P, I and $\mathrm{H}$ are respectively the number of products, industries and household types considered as endogenous in the model (the superscripts $h$ and $k$ also refer to endogenous household types).

This model uses a rectangular supply and use format where each industry produces one or more products (Oosterhaven, 1984; Miller and Blair, 2009: Chapter 5). The data have a significant level of detail concerning both the number of products (431) and the industries (134) that produce them. An innovative feature of the CSA is that it covers three household types whose income and consumption are endogenous, i.e., households whose main source of income is labor (including own-account 
workers), divided into noncommuters, commuters and beneficiaries of real estate rents (landlords). As such, the reference to households ( $h$ and $k$ ) in $\mathbf{H C}, \mathbf{H I}$ and $\mathbf{R}$ relates to household consumption, income, and the rents received and paid by these three household types. Otherwise, other household types' expenditure and demand are considered to be exogenous.

The core of this extended MRIO, which is contained within the bold border in Table 1 that comprises the supply and use matrices, is further transformed to compute the Leontief Inverse. The supply (or production) matrices $\mathbf{P}$ describe each industry product production structure, i.e., the products produced by each industry in each region. Industries produce one (or more) primary products but they may also produce other products through secondary production. In the Use matrix, the consumption of inputs by each industry (IC) or endogenous household type (HC) in each region is described according to its regional origin: they may be produced in the region where they are used, or they may be traded interregionally_so-called "inflows". The Use matrix in this model includes regional income flows from industries to households (HI) and from households to households $(\mathbf{R})$, living in the same or another region.

According to MULTI2C procedures, net interregional trade (exports less imports, by commodity) is estimated by the residue method (i.e., by the difference between other sources of regional supply and demand). Interregional gross imports are then estimated by examining the nature of each product and following the method described in Ramos et al. (2015). There, products are classified into three types: as regionally nontradable, fully tradable internationally and interregionally, or regionally tradable between specific locations. Gross exports are given by adding gross imports to net trade.

The regional matrices are "domestic flows", i.e., they concern products produced within regional economies and national borders (international imports are treated separately - M and TM). All transactions are in "basic prices", i.e., without value-added taxes or other taxes (less subsidies) on products (T). Finally, trade and transportation margins are treated as inputs provided by Retail and Wholesale Trade Services or Transport Services (included in IC and HC).

Other final demand (OFD) includes the consumption by other household types not considered in the core of the matrix, i.e., exogenous household types whose expenditures are assumed not to depend systematically on industries' income distribution (households living mainly on capital income less rents, on pensions and on other social transfers). OFD also includes the general government and nonprofit institutions serving households' final consumptions, investment, the final consumption in each region of nonresidents in the country, the international exports of goods and services, and can also cover negligible residues generated in the interregional trade estimation process. 


\subsection{Regional income distribution}

The share of income distributed by each industry in each region is a central element for deriving the CSA as commuting is more intensive in metropolitan areas (Gardner and Marlay, 2013). The consideration of regional income distribution in IO frameworks was proposed by Madden and Batey (1983) and explored in a bit more depth by Oosterhaven and Folmer (1985). The adaptation to MRIO frameworks was suggested in the works of Jun (1999; 2004) and Hewings et al. (2001). Madsen and Jensen-Butler (2005) also considered commuting as an activity involving the generation of GVA outside the region and brought into the region as income.

The research approach proposed here explicitly considers splitting the households' income (HI) between commuter and noncommuter household types that are both included in the endogenous part of the model (as separate earnings of each type). The research convention is that noncommuter households are those living in the same municipality in which they work, while commuters live in a different municipality (or even region) from their workplace. Thus, a share of labor and own-account workers' mixed income is distributed to households that commute between different municipalities within the same region and to households that commute between regions. The interregional distribution of labor and mixed income is confined to the specific type of commuter households. Noncommuter households, however, receive this type of income exclusively from industries within the same region. Finally, the regional labor income distribution by household and region depends on the origin-destination commuting matrices, by industry. ${ }^{2}$ Given these characteristics, this extended MRIO model allows a more realistic assessment of the effects generated by a shock, e.g., in the demand for a specific product. If one region's industry changes its production as the income is distributed between commuter and noncommuter households, the effects of this shock are felt in different regions and in the consumption by each household type.

\subsection{Household consumption structures}

Regional income distribution occurs simultaneously with other commuting-related consequences. Commuting influences households' regional consumption in two significant ways: it influences what they buy (Ferreira et al., 2014) and where they buy it. Households near the large employment centers tend to spend more on house rents and local services and less on fuel and other commuting related products such as cars, maintenance, tolls, and insurance. Additionally, commuters not living in the

\footnotetext{
${ }^{2}$ In fact, some households have members that are commuters and others that are not. This model notionally splits these households to account for their commuting status, such that the commuter members feed the commuter consumption bundle and the others the non-commuter consumption.
} 
region of their workplace tend to purchase many products in the region where they live-mainly nontradable products like housing, electricity, and water services - and make other purchases in both their living and working regions. These distinct consumption patterns have implications for the location where the consumption actually takes place and have an effect on each region's households demand structure. Thus, a change in this structure also has an important impact on the economy (Kim et al., 2015).

So, in its endogenous part the CSA framework considers household groups by main source of income (labor or real estate renting). Moreover, given the implications of the commuting activity in households' consumption structures, the earnings and expenditures of those mainly living from labor and mixed income are divided between commuters and noncommuters. This distinction is relevant to adapting our model to a metropolitan region with intensive commuting. Finally, the consumption by other (exogenous) household types is considered in the OFD and all the household types considered have different consumption structures in the different regions.

\subsection{Real estate renting activities}

Commuting patterns influence the extent and density of a specific metropolitan area. While influencing regional distribution of income and household expenditure, commuting is also closely linked with the housing market and other real estate rents. As expenditure on real estate rents has been highly correlated with density, potential commuting pattern changes that affect housing and firm location also affect this particular expenditure type. Moreover, these changes lead to an income redistribution that can benefit or prejudice those whose income comes from real estate revenues in different regions.

So, the CSA also considers another household type that benefits from an endogenous income: those living mainly on property rents they collect. These households benefit both from income from renting business offices or other industrial buildings (included in HI) and from income earned specifically from renting houses $(\mathbf{R})$. Rents can also be received by firms. Real estate rents can be paid by industries or households to industries and households located either in the same region or in a different one. Naturally, the interregional distribution of rent occurs not from commuting itself, but the fact that some real estate owners do not live in the same region as the properties that they lease to others.

\subsection{Integrating CSA components: a closed MRIO model with environmental extension}

Commuting is one of the major causes of environmental externalities within metropolitan regions (Muñiz and Galindo, 2005) and changing commuting patterns influence energy consumption and $\mathrm{CO}_{2}$ emissions. So, our model is further extended to deal with both environmental and energy issues, using 
a specific extension for the primary energy consumption by industry. This energy/environment module first evaluates the changes in the consumption of oil and its derivatives, natural gas and coal (in physical units), before estimating the $\mathrm{CO}_{2}$ emissions corresponding to this fossil fuel combustion.

To sum up, the components and links in our model are developed in order to ensure commuting data is organized in a framework consistent with the national accounts system, thus meeting the requirements established by the UN (2009) and Eurostat (2013) guidelines for it to qualify as a satellite account. The specific design of this integrated modeling framework therefore allows the implementation of an innovative estimation rationale. Changes in commuting modify households' consumption in two ways: in that they change the region where the consumption of certain products occurs and also cause a shift in the consumption structure. This modeling framework is also designed to consider possible changes in the distribution of rent income caused by modifications in commuting patterns. Finally, the energy uses and environmental impacts of commuting pattern changes are also assessed.

\section{The CSA applied to the Lisbon Metropolitan Area}

This section presents the CSA case study as applied to the Lisbon Metropolitan Area (LMA). In Portugal, this region has the most intensive commuting. For the purpose of this application, commuting is defined as travel-to-work journeys between different municipalities within a metropolitan area or from/to municipalities outside the metropolitan area.

For statistical purposes, the LMA is a NUTS II region comprising two NUTS III subregions (Greater Lisbon and Peninsula de Setúbal). This work considers the Peninsula de Setubal as a peculiar case within the LMA because it is separated from the northern part of the region by a physical barrier, the River Tagus: only two bridges connect the two sides. In spite of this, there are intense commuting flows between the two subregions, with the Peninsula de Setúbal depending economically heavily on these movements. In 2011, the LMA accounted for 38\% of Portugal's gross domestic product, $29 \%$ of national employment and $42 \%$ of all commuters in Portugal. 
Figure 1. Map of Portugal and Lisbon Metropolitan Area

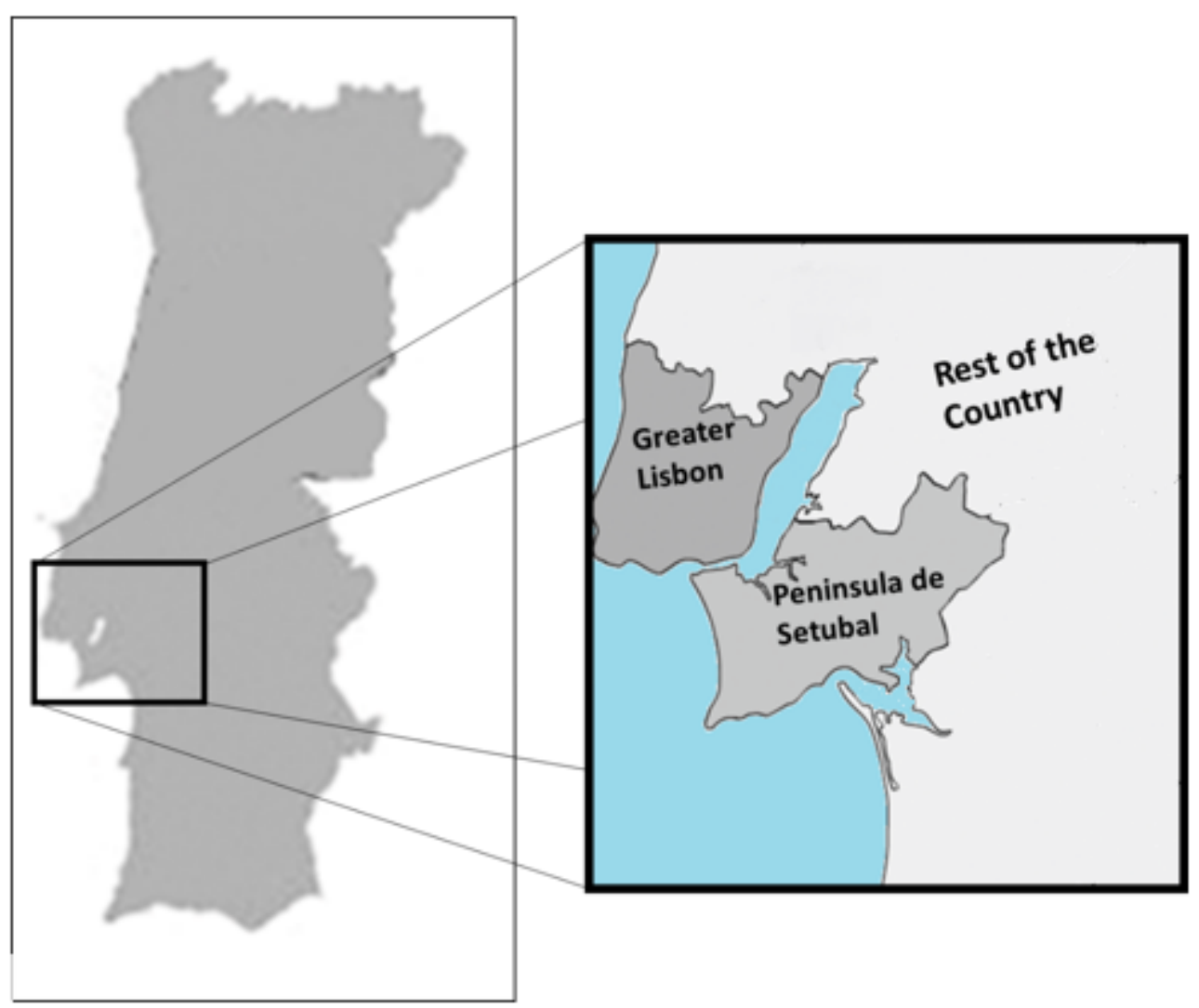

Table 2 shows the origin-destination of workers/residents in the LMA according to Portugal's 2011 Census. This case study does not consider commuting by those who both work and live in the rest of Portugal.

Table 2. LMA workers origin-destination matrix

\begin{tabular}{|c|c|c|c|c|}
\hline \multirow{2}{*}{ 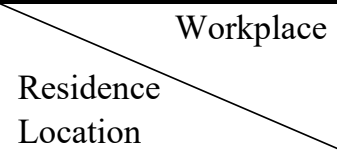 } & \multirow{2}{*}{$\begin{array}{c}\text { Same } \\
\text { municipality } \\
\text { (non-commuters) }\end{array}$} & \multicolumn{3}{|c|}{ Other municipalities (commuters) } \\
\hline & & $\begin{array}{l}\text { Greater } \\
\text { Lisbon }\end{array}$ & $\begin{array}{l}\text { Peninsula } \\
\text { Setúbal }\end{array}$ & $\begin{array}{l}\text { Rest of the } \\
\text { Country }\end{array}$ \\
\hline Greater Lisbon & 484,396 & 370,776 & 13,633 & 13,044 \\
\hline Peninsula Setúbal & 155,365 & 98,762 & 60,521 & 4,048 \\
\hline Rest of the Country & ------ & 36,138 & 3,855 & ---- \\
\hline
\end{tabular}

Source: Own calculations based on 2011 Census (INE, 2012)

According to Table 2, around $45 \%$ of the workers living in the LMA are commuters. Of those living in the Greater Lisbon NUTS III subregion, 55\% are noncommuters, $42 \%$ travel between municipalities within the Greater Lisbon NUTS III subregion and 3\% travel to Peninsula de Setubal and to the Rest of the Country to work. In Peninsula de Setubal, $48 \%$ of its employed or self-employed inhabitants are noncommuters, $19 \%$ travel between municipalities within the Peninsula de Setúbal NUTS III 
subregion and more than $30 \%$ travel to the Greater Lisbon NUTS III subregion to work. This is by far the most intensive commuting activity between any of Portugal's NUTS III subregions.

The Peninsula de Setúbal is mainly a manufacturing region. Still, it suffers a sizeable trade deficit both in terms of international and interregional trade. It seems that this deficit is the counterpart, at the regional balance of payments level, of the income inflows associated with the commuting phenomenon. The Greater Lisbon NUTS III subregion, however, has a relatively steady trade balance, with a deficit at international level offset by surpluses at the regional level. The net exports (international and interregional) from the Greater Lisbon region are associated mainly with wholesale trade activities, financial services, passenger air transportation and the manufacture and provision of natural gas. Many of these net exports are due to many Portuguese firms having their headquarters in the City of Lisbon (Ferreira, 2016). ${ }^{3}$

\section{The opportunity costs of commuting in the LMA}

In this section, the commuting satellite account is embodied in a tri-regional input-output framework applied to the two NUTS III subregions of the LMA - Greater Lisbon and Peninsula de Setúbal - and to the Rest of the Country, for 2010. Our goal is to assess the social, economic and environmental impacts of commuting by estimating the opportunity costs associated with a scenario that consists of hypothetically relocating the commuters' place of residence to the municipality in which they work.

\subsection{Scenario construction - methodological issues}

Starting in Table 1, the first step is to compute input coefficients in the core matrix by dividing each of its cells by the corresponding total domestic product supplies (x), industries' total production (q) and total household incomes $\left(\mathbf{y}^{\mathrm{h}}\right)$, i.e., by the corresponding values in the bottom row of Table 1 . This procedure leads to two sets of input coefficients, the sub-matrices $\mathbf{B}$ and $\mathbf{D}$, which represent the nationally produced inputs used in the industries' production processes (and the household budget coefficients as a proportion of their total income, by household type) and each industry's share in a specific product production, respectively. The dimensions of $\mathbf{B}$ are $[R \times(P+H)] \times[R \times(I+H)]$ where $\mathrm{R}$ is the number of regions, $\mathrm{P}$ the number of products and $\mathrm{H}$ the number of endogenous households: $\mathrm{R}=3, \mathrm{P}=431$ and $\mathrm{H}=3$ in this application. The dimensions of $\mathbf{D}$ are $[\mathrm{R} \times(\mathrm{I}+\mathrm{H})] \times \mathrm{R} \times(\mathrm{P}+\mathrm{H})]$. Therefore, $\mathbf{A}$, the total input coefficients square matrix, takes the form:

\footnotetext{
${ }^{3}$ Our model follows the regional accounts rule in that it allocates the economic activity to the place where it actually happens (and not entirely to the firm's headquarters). In spite of this, the contribution of the headquarters to the production activity is very significant in several industries, such as financial services, for instance. In our model this explains the significance of interregional exports from the Greater Lisbon region.
} 


$$
\mathbf{A}=\left[\begin{array}{ll}
0 & \mathbf{B} \\
\mathbf{D} & 0
\end{array}\right]
$$

Then,

$$
\mathbf{L}=(\mathbf{I}-\mathbf{A})^{-\mathbf{1}}
$$

is a multiplier matrix, which, as is usual in a rectangular model, can be divided into four different quadrants:

$$
\mathbf{L}=\left[\begin{array}{ll}
\mathbf{L}_{11} & \mathbf{L}_{12} \\
\mathbf{L}_{21} & \mathbf{L}_{22}
\end{array}\right]
$$

$\mathbf{L}_{11}$ and $\mathbf{L}_{21}$ are the submatrices representing, respectively, the impacts on products and industries' outputs of unitary variations in the OFD. The last three rows of each of these sub-matrices concern the impacts on the income of the three (endogenous) household types of those variations in the OFD. $\mathbf{L}_{12}$ and $\mathbf{L}_{22}$ calculate the same kind of impacts when the $\mathbf{O F D}$ variations are not disaggregated by products, as usually happens, but are instead directly reallocated to the industries.

The implementation of the scenario requires a transformation in matrix $\mathbf{A}$ (specifically in submatrix B). As commuting ceases, this means that the income distributed by each industry will no longer be distributed to commuter households. The corresponding rows then become 0 (null) in all their entries. The labor and mixed income is now entirely distributed to households that do not commute, within the region where the industries are located. This new territorial distribution of income also reallocates the households' consumption between the regions. Moreover, the overall consumption structure is also affected since commuter consumption vanishes and all households living from labor are now assumed to follow the non-commuters' consumption structure patterns.

It is important to note that in this scenario the Other final demand (OFD) does not change because no commuting by the household types included in the OFD is assumed at the outset. Then the new ' ' and $\mathbf{y}^{\mathrm{h}}$, are obtained by:

$$
\mathbf{z}^{\prime}=\mathbf{L}_{21}^{*} \times \mathbf{O F D}
$$

where $\mathbf{z}^{\prime}=\left[\begin{array}{l}\mathbf{q}^{\prime} \\ \mathbf{y}^{\mathrm{h}}\end{array}\right]$ and $\mathbf{L}_{\mathbf{2 1}}^{*}$ is the new $\mathbf{L}_{\mathbf{2 1}}$, after the transformation of $\mathbf{A}$.

Furthermore, this MRIO-based modelling framework allows the integration of the CSA components with the energy requirements and related $\mathrm{CO}_{2}$ emissions. We use the approach, albeit for a national economy, of Cruz (2009) and Cruz and Barata (2012) in an MRIO context to estimate 
regional sectoral primary energy intensities per unit of total output (in toe/million EUR). We then estimate the primary energy requirements and the corresponding $\mathrm{CO}_{2}$ emissions embodied in a given structure of regional production and consumption. ${ }^{4}$

\subsection{Economic, social and environmental impacts of commuting}

In this subsection, the results of the scenario applied to the LMA are presented in the context of the CSA model application. Table 3 gives the initial values for output, value added, and the labor income of endogenous households, employment, energy consumption and $\mathrm{CO}_{2}$ emissions, for each region and for the Portuguese economy as a whole. The estimated changes induced by the hypothetical scenario are presented below.

Table 3. Economic, social and environmental impacts of changes in commuting patterns

\begin{tabular}{|c|c|c|c|c|}
\hline & $\begin{array}{l}\text { Greater } \\
\text { Lisbon }\end{array}$ & $\begin{array}{c}\begin{array}{c}\text { Peninsula } \\
\text { de }\end{array} \\
\text { Setúbal } \\
\end{array}$ & $\begin{array}{l}\text { Rest of the } \\
\text { Country }\end{array}$ & TOTAL \\
\hline \multicolumn{5}{|l|}{ Baseline (2010) } \\
\hline Output $\left(10^{6} €\right)$ & 99,588 & 18,566 & 192,393 & 310,357 \\
\hline $\operatorname{GVA}\left(10^{6} €\right)$ & 45,871 & 7,413 & 86,819 & 140,102 \\
\hline $\begin{array}{l}\text { Resident Endogenous Households } \\
\text { Income }\left(10^{6} €\right)\end{array}$ & 28,355 & 8,482 & 62,440 & 99,277 \\
\hline Employment $\left(10^{3} \mathrm{FTE}\right)$ & 1,204 & 252 & 3,337 & 4,793 \\
\hline Coal $\left(10^{3}\right.$ toe $)$ & 9 & 8 & 1,640 & 1,657 \\
\hline Natural Gas $\left(10^{3}\right.$ toe $)$ & 573 & 185 & 3,749 & 4,507 \\
\hline Oil and its derivatives $\left(10^{3}\right.$ toe $)$ & 2,411 & 544 & 6,609 & 9,564 \\
\hline $\mathrm{CO}_{2}$ Emissions $\left(10^{3}\right.$ tons $)$ & 8,636 & 2,130 & 35,040 & 45,806 \\
\hline \multicolumn{5}{|l|}{ Scenario $(\Delta)$} \\
\hline Output $\left(10^{6} €\right)$ & 1,757 & -381 & -65 & 1,312 \\
\hline $\operatorname{GVA}\left(10^{6} €\right)$ & 921 & -216 & -43 & 662 \\
\hline $\begin{array}{l}\text { Resident Endogenous Households } \\
\text { Income }\left(10^{6} €\right)\end{array}$ & 4,548 & $-3,207$ & -850 & 491 \\
\hline Employment $\left(10^{3} \mathrm{FTE}\right)$ & 29 & -8 & 0 & 21 \\
\hline Coal $\left(10^{3}\right.$ toe $)$ & 0 & -1 & 17 & 17 \\
\hline Natural Gas $\left(10^{3}\right.$ toe $)$ & 14 & -4 & 23 & 33 \\
\hline Oil and its derivatives $\left(10^{3}\right.$ toe $)$ & -34 & -77 & -42 & -153 \\
\hline $\mathrm{CO}_{2}$ Emissions $\left(10^{3}\right.$ tons $)$ & -73 & -238 & -4 & -316 \\
\hline
\end{tabular}

\footnotetext{
4 According to Choi (2015), the regional environmental responsibilities associated with energy requirements and corresponding $\mathrm{CO}_{2}$ emissions attributable to regional production activities can be distinguished as those meeting regional (type 1) and out-of-region (type 2) demand. For the purposes of this analysis, as commuting in the LMA is deemed to occur within national borders, the type 2 variations on energy use and $\mathrm{CO}_{2}$ emissions should only consider changes in interregional demand, meaning that these estimations do not involve changes in international demand satisfied by regional production activities.
} 
Table 3 gives the estimated results at both regional and national level. According to the simulation, the expected impacts on global economic activity and employment are positive in the Greater Lisbon region, and more than offset the anticipated losses in the Peninsula de Setubal and the Rest of the Country, which lose part of their population. At the national level, the outcomes mirror the change in the structure of endogenous household consumption, considering that the total OFD stays stable in both regions. In sectoral terms, there is a reduction in the consumption of several products that require large shares of international inputs (e.g., fuel, water and rail public transportation), or that are almost exclusively imported, such as cars, which are consumed more heavily by commuters, or whose purchase prices contain a significant indirect tax burden. The estimated contractions are offset by expansion of other kinds of consumption, in particular goods and services that incorporate a greater share of national value added. Thus, an expansionist effect is found for most of the industries, with exceptions being the more commuting-related ones such as passenger transport either by water, rail or road and the manufacture of refined petroleum products.

At the regional level, Greater Lisbon is confirmed as the only region to benefit from the hypothetical change in households' place of residence. Indeed, it benefits both from the abovementioned change in the consumption structure and from the increase in demand, since the number of households living in this region increases. This mostly affects the output of industries that locally provide non-tradable products or services, notably water collection and treatment, the retail trade, households as employers of domestic personnel, and food and beverage service activities. Conversely, these are the industries that decline the most in the Peninsula de Setubal, as the number of residents in this region decreases. However, this decline is mitigated by the expansion felt in the national economy since it helps to increase the output of industries that depend mostly on national demand. These industries include electricity production, the food processing, the manufacture of pulp and paper products, and the manufacture of rubber and plastic products. This partial economic expansion is also anticipated for the rest of the Portugal as well. So, the impacts of this scenario suggest that reduced commuting alone should lead to positive effects on the economy as a whole.

Finally, besides improving the economy and employment, this change in commuting patterns also contributes to a moderate, but still positive, impact on energy consumption savings and $\mathrm{CO}_{2}$ emissions, with a $0.7 \%$ reduction in national greenhouse gas emissions. ${ }^{5}$ This overall net result is mainly driven by the fall in the consumption of oil and its derivatives, though, as the economy grows, coal and natural gas consumption expands somewhat.

${ }^{5}$ These results are in line with Wier et al. (2001), regarding the influence of distinct household consumption patterns on $\mathrm{CO}_{2}$ emissions. 


\subsection{Changes in real estate rents}

Commuting pattern changes imply a modification to the real estate rents paid and received by different economic agents for housing, offices, or other commercial and industrial space. This model is adjusted to handle the possibility of changes in renting activities. Indeed, rents are expected to change as people or businesses agglomerate or disperse. The above scenario is supplemented by a sensitivity analysis that assesses possible exogenous changes in the distribution of rent income accruing from the demand for houses in central Lisbon. More specifically, we simulate two sub-scenarios, where the residential rents rise by either $20 \%$ or $50 \%$ within the region in which population and economic activity grow. The counterpart of this rent change is a reduction in other consumption, such that total household expenditures are essentially assumed to be fixed. The results of those sub-scenarios for Portugal as a whole are presented in Table 4.

Table 4. Sensitivity analysis on real estate rent changes

\begin{tabular}{cr|r|r}
\hline & $\begin{array}{c}\text { Output } \\
\left(\mathbf{1 0}^{\mathbf{6}} \boldsymbol{\epsilon}\right)\end{array}$ & $\begin{array}{c}\text { GVA } \\
\left(\mathbf{1 0}^{6} \boldsymbol{\epsilon}\right)\end{array}$ & $\begin{array}{c}\text { Employment } \\
\left(\mathbf{1 0}^{3} \boldsymbol{F T E}\right)\end{array}$ \\
\hline Scenario $(\boldsymbol{\Delta})$ & & & \\
\hline No Rents Change & 1,312 & 662 & 21 \\
\hline $20 \%$ increase & 1,184 & 615 & 19 \\
\hline $50 \%$ increase & 993 & 545 & 15 \\
\hline
\end{tabular}

Table 4 shows that despite the substantial changes in the property rent value the results broadly confirm the findings in Table 3. The main reason is that, although rents are treated as a cost borne by households or firms, in macroeconomic terms, this specific cost is not a significant burden to the broader economy since it is redistributed among economic agents. So, an increase in house rents paid by households is dealt with as a net transfer of income among different household group to the benefit of those whose main source of income is real estate rents. This produces a small macroeconomic loss because, according to our estimates, landlords have a higher propensity to save than do households that rely mainly on labor income, the main net rent-paying group.

Summing up, sensitivity analysis yields some important conclusions: first, society sustains an economic cost if extensive commuting flows prevail; second, this cost is non-neutral at regionally; third, commuting imposes important environmental externalities, and finally, the potential impacts of commuting pattern changes on real estate renting activities only marginally affect the other conclusions. 


\section{Conclusions}

Commuting influences regional and urban economies as much as, or even more than, other types of interregional economic flows. But the role of commuting in local and regional economies worldwide has not been analyzed much empirically. So reliable data are needed on the magnitude of the commuting phenomenon using the concepts, definitions and approaches that are applied to other activities. This work is the first that uses input-output data and a set of satellite accounts on commuting to study the complexity of commuting flows and their multi-dimensional impacts.

The commuting satellite accounts (CSA) framework we propose sheds some light on commuting and its impacts. The CSA used was designed specially to assess changes in worker commuting patterns that affect (1) the regional distribution of labor compensations and own-account workers' mixed income, (2) differential consumption patterns among households, (3) real estate rents, and (4) the environmental emissions. As such, it opens up new research avenues to assess changes in urban form, commuting patterns, and alternative housing or workplace locations. The fact that it incorporates in a multi-regional input-output framework enables the potential to evaluate multi-dimensional (economic, social and environmental) general equilibrium effects in different geographical contexts.

The application of this framework to the Lisbon Metropolitan Area (LMA) demonstrates the potential usefulness of our innovation. Indeed, we show that if current LMA commuters lived closer to their workplaces, important savings would likely to emerge in terms of economic, social and environmental opportunity costs. Additionally, the expected changes in households' consumption structure (including less consumption of products that require a larger proportion of internationally imported inputs) expands the national economy somewhat. For the LMA, the output loss in Lisbon's suburbs would be more than offset by enhanced productivity in Greater Lisbon. This is underlined by falling total energy consumption and $\mathrm{CO}_{2}$ emissions.

Though commuting never will be eliminated completely, our simulations or ones similar to them could useful for guiding policies and strategies that are aimed toward reducing both urban sprawl and $\mathrm{CO}_{2}$ emissions. Urban and regional planning matters. Further, land-use policy can favor less sprawled regions and, consequently, less commuting. Finally, the decision to commute depends largely on rents, transportation costs, and household incomes. Therefore, when local, regional or federal governments decide to build new highways, bridges, or other public transportation infrastructure, they are in fact subsidizing those households and institutions that most intensively use that infrastructure. On the contrary, when the cost burden of infrastructure falls on commuters themselves commuting is dampened - at least in the long term. These strategies can be complemented by, for example the 
introduction of congestion tolls (already applied, with different specifications, in London, Singapore, Durham or Milan), fuel taxes, graduated motor vehicle registration fees and/or parking policies to reduce traffic in the city centers (Verhoef et al. 1995; Barata et al., 2011).

\section{References}

Barata, E., L. Cruz and J.-P. Ferreira (2011) Parking at the UC campus: Problems and Solutions. Cities, 28, 406-413.

Choi, T. (2015) Understanding Environmental Responsibility of Cities and Emissions Embodied in Trade. Economic Systems Research, 27, 133-153.

Cruz, L. (2009) Application of IO Energy Analysis for $\mathrm{CO}_{2}$ Emissions by the Portuguese Economy. In: S. Suh (ed.) Handbook of Input-Output Economics in Industrial Ecology. Eco-Efficiency in Industry and Science, 23. Springer, pp. 507-532.

Cruz, L. and E. Barata (2012) Hybrid IO Analysis of $\mathrm{CO}_{2}$ Emissions: An Application to the Portuguese Economy. In: M. Llop (ed.) Air Pollution: Economic Modelling and Control Policies. Environmental Sciences Series. Bentham Science Publishers, pp. 65-95.

Ewing, R. (1997) Is Los Angeles-style Sprawl Desirable? Journal of the American Planning Association, 63, 107-126.

Eurostat (2013) European System of national and regional Accounts - ESA 2010. Publications Office of the European Union, Luxembourg.

Ferreira, J.-P., E. Barata, P. Ramos and L. Cruz (2014) Economic, Social, Energy and Environmental Assessment of Inter-municipality Commuting: The Case of Portugal. Energy Policy, 66, $411-$ 418.

Ferreira, J.-P. (2016) How Commuting Influences Urban Economies and the Environment: A Commuting Satellite Account Applied to the Lisbon Metropolitan Area. Unpublished Ph.D. dissertation in Sustainable Energy Systems, University of Coimbra, Portugal.

Fujita, M., P. Krugman, and T. Mori (1999) On the Evolution of Hierarchical Urban Systems. European Economic Review, 43, 209-251.

Gardner, T. and M. Marlay (2013) Whither the Jobs: Identifying Concentrations of Employment in Metropolitan Areas. Urban Geography, 34, 37-41.

INE (2012) Census 2011. Database of the Official Statistics Portal, Statistics Portugal, Lisbon, Portugal. 
IPCC (2006) 2006 IPCC Guidelines for National Greenhouse Gas Inventories. Prepared by the National Greenhouse Inventory Program, H. Eggleston, L. Buendia, K. Miwa, T. Ngara T. and K. Tanabe K. (eds). IGES, Japan.

Jun, M. (1999) An Integrated Metropolitan Model Incorporating Demographic-Economic, Land-Use and Transport Models. Urban Studies, 36, 1399-1408.

Jun, M. (2004) A Metropolitan Input-Output Model: Multisectoral and Multispatial Relations of Production, Income Formation, and Consumption. Annals of Regional Science, 38, 131-147.

Kim, K., G.J.D Hewings and K. Kratena (2015) The Extended Econometric Input-Output Model with Heterogeneous Household Demand System. Economic Systems Research, 27, 257-285.

Madden, M. and P. Batey (1983) Linked Population and Economic Models: Some Methodological Issues in Forecasting Analysis and Policy Optimization. Journal of Regional Science, 23, 141164.

Madsen, B. and C. Jensen-Butler (2005) Spatial Accounting Methods and the Construction of Spatial Social Accounting Matrices. Economic Systems Research, 17, 187-210.

Malpezzi, S. (1996) Housing Prices, Externalities, and Regulation in U.S. Metropolitan Areas. Journal of Housing Research, 7, 209-241.

Miller, R.E. and P.D. Blair (2009) I-O Analysis: Foundations and Extensions, $2^{\text {nd }}$ ed. Cambridge University Press, New York.

Muñiz, I. and A. Galindo (2005) Urban Form and the Ecological Footprint of Commuting. The Case of Barcelona. Ecological Economics, 55, 499-514.

Naess, P. (2010) Residential Location, Travel and Energy Use: The Case of Hangzhou Metropolitan Area. Journal of Transport and Land Use, 3, 27-59.

Oosterhaven, J. (1984) A Family of Square and Rectangular Interregional Input-Output Tables and Models. Regional Science and Urban Economics, 14, 565-582.

Oosterhaven, J. and H. Folmer (1985) An Interregional Labour Market Model Incorporating Vacancy Chains and Social Security. Papers of the Regional Science Association, 58, 141-155.

Ramos, P., L. Cruz, E. Barata, A. Parreiral and J.-P. Ferreira (2015) A Bi-Regional (Rectangular) Input-Output Model for Portugal: Centro and Rest of the Country. In: P. Godinho and J. Dias (eds.) Assessment Methodologies: Energy, Mobility and Other Real World Applications. Coimbra: Imprensa da Universidade de Coimbra, pp. 265-286.

UN (2009) System of National Accounts 2008. European Communities, International Monetary Fund, Organization for Economic Co-operation and Development, United Nations and World Bank. United Nations Publications, New York. 
Verhoef, E., P. Nijkamp and P. Rietveld (1995) Second-best Regulation of Road Transport Externalities. Journal of Transport Economics and Policy, 29, 147-167.

Wier, M., M. Lenzen, J. Munksgaard and S. Smed (2001) Effects of Household Consumption Patterns on $\mathrm{CO}_{2}$ Requirements. Economic Systems Research, 13, 259-274. 